BUDGETING : Journal of Business, Management and Accounting

Volume 2, Nomor 2, Januari-Juni 2021

e-ISSN: 2715-2480

p-ISSN: $2715-1913$

DOI: https://doi.org/10.31539/budgeting.v2i2 1752

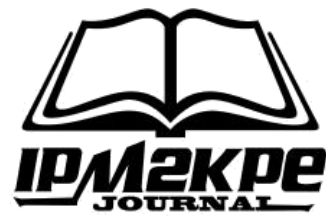

\title{
EVALUASI TRANSAKSI MUDHARABAH BERDASARKAN PSAK 105 PADA BANK SYARIAH
}

\author{
Muhammad Robi ${ }^{1}$, Moh. Halim ${ }^{2}$, Suwarno $^{3}$ \\ Universitas Muhammadiyah Jember ${ }^{1,2,3}$ \\ robi2020@gmail.com ${ }^{1}$
}

\begin{abstract}
ABSTRAK
Penelitian ini bertujuan untuk mengidentifikasi kepatuhan penerapan transaksi Mudharabah yang terjadi pada Bank Syariah Mandiri Cabang Jember berdasarkan PSAK 105 (Akuntansi Mudharabah) dalam pandangan perlakuan akuntansi. Penelitian ini menggunakan teknik wawancara dan dokumentasi sebagai metode pengumpulan data dan sumber data diperoleh dari data primer dan sekunder. Metode analisis yang digunakan adalah menggunakan teknik analisis data kualitatif deskriptif yang dilakukan dengan cara membandingkan penerapan yang terjadi di Bank Syariah Mandiri Cabang Jember dengan PSAK 105 (Akuntansi Mudharabah). Hasil penelitian menunjukkan bahwa penerapan akad Mudharabah di Bank Syariah Mandiri Cabang Jember sebagian besar kriteria PSAK 105 telah terpenuhi, namun ada beberapa pernyataan yang belum sesuai dengan PSAK 105, yaitu Bank Syariah Mandiri Cabang Jember dalam transaksi Mudharabah hanya menggunakan aset dalam bentuk kas untuk pendanaan, tidak melakukan pendanaan Mudharabah dalam bentuk asset non kas. Simpulan, Pengakuan, pengukuran, penyajian dan pengungkapan transaksi Mudharabah di Bank Syariah Mandiri Cabang Jember sudah hampir sesuai dengan PSAK 105.
\end{abstract}

Kata Kunci: Evaluasi, PSAK 105, Transaksi Mudharabah

\section{ABSTRACT}

This study aims to identify compliance with the implementation of Mudharabah transactions that occur at Bank Syariah Mandiri Branch of Jember based on PSAK 105 (Mudharabah Accounting) because of accounting treatment. This study used interviews and documentation techniques as data collection methods and obtained data from primary and secondary data. The analytical method used is to employ descriptive qualitative data analysis techniques that are carried out by comparing the implementation in Bank Syariah Mandiri Branch of Jember with PSAK 105 (Mudharabah Accounting). The results showed that the performance of the Mudharabah contract at Bank Syariah Mandiri Branch of Jember, most of the criteria for PSAK 105 had been fulfilled. Still, several statements were not following PSAK 105, namely Bank Syariah Mandiri Branch Jember in Mudharabah transactions only using assets in the form of cash for funding. It does not conduct Mudharabah funding in the state of non-cash assets. Conclusion, recognition, measurement, presentation and disclosure of Mudharabah transactions at Bank Syariah Mandiri Jember Branch are almost following PSAK 105.

Keywords: Evaluation, PSAK 105, Mudharabah Transactions 


\section{PENDAHULUAN}

Perkembangan praktik Lembaga Keuangan Syariah di level internasional telah memberikan gambaran bahwa Sistem Ekonomi Islam Syariah mampu beradaptasi dengan perekonomian konvensional yang telah berabad-abad menguasai kehidupan masyarakat dunia. Memang Bank berdasarkan syariah ini tergolong baru dikalangan kita, Malaysia sudah mengenalnya sejak 10 Tahun yang lalu. Di negara lain seperti Arab Saudi, Mesir, Jordan, Pakistan, Kuwait Luxemburg, bahkan sudah lebih dahulu mempraktekkannya (Harahap, 1997).

Negara Indonesia baru memulai Praktek lembaga perbankan dan keuangan pada tahun 1992 dengan didirikannya Bank Muamalat Indonesia (BMI). Meningkatnya kesadaran masyarakat atas pelayanan keuangan berbasiskan syariah, memotivasi lahirnya lembaga keuangan syariah lain. Di dalam transaksi dan kegiatannya, prinsipprinsip islam yang di terapkan oleh bank syariah yaitu transaksi keuangan dengan konsep bagi hasil, salah satu konsep bagi hasil tersebut adalah akad Mudharabah. Mudharabah adalah akad kerjasama usaha antara dua pihak dimana pihak pertama (pemilik dana) menyediakan seluruh dana, sedangkan pihak kedua (pengelolah dana) bertindak selaku pengelolah, dan keuntungan dibagi antara mereka sesuai kesepakatan sedangkan kerugian finansial hanya ditanggung oleh pemilik dana (Mustofa, 2016). Namun dalam kenyataan di lapangan yang banyak dipakai oleh nasabah Bank Syariah pada umumnya adalah produk perbankan syariah berupa sistem yang berlandaskan jual beli yang dikenal dengan istilah Murabahah.

Bank syariah Mandiri merupakan Bank Syariah yang unggul di Indonesia, salah satu cabangnya berada di kabupaten Jember yang pertama kali beroperasi pada tanggal 1 Desember 2007, prinsip islam yang diterapakan sama dengan bank syariah lain yaitu transaksi keuangan dengan konsep bagi hasil (Mudharabah), namun ada beberapa kendala yang dihadapi yaitu pihak bank mandiri mengakui terdapat beberapa transaksi yang belum sesuai dengan PSAK 105 sehingga masih ada yang perlu dikoreksi. Oleh karena itu, peneliti tertarik untuk mengkaji tentang kepatuhan penerapan transaksi Mudharabah yang terjadi pada Bank Syariah Mandiri Cabang Jember berdasarkan PSAK 105 (Akuntansi Mudharabah) dalam pandangan perlakuan akuntansi. 


\section{KAJIAN TEORI}

\section{Bank Syariah}

Bank syariah merupakan suatu sistem bank yang pelaksanaan kegiatannya berdasarkan ajaran islam dan hukum islam. Sistem perbankan syariah dibentuk karena adanya larangan dalam agama islam untuk memungut ataupun meminjam dengan menggunakan bunga (riba). Undang-undang RI No. 21 Tahun 2008 tentang perbankan syariah menyebutkan bahwa perbankan syariah bertujuan untuk menunjang pelaksanaan pembangunan nasional dalam rangka meningkatkan keadilan, kebersamaan dan pemerataan kesejahteraan rakyat, pemerataan kesejahteraan yang dimaksud diwakili oleh indeks gini merupakan suatu angka yang menggambarkan tingkat kesenjangan kesejahteraan masyarakat suatu negara. Semakin besar angka pada indeks gini maka semakin besar pula tingkat kesejangan kesejahteraan masyarakat (Hidayat \& Surahman, 2017).

\section{Mudharabah}

Mudharabah adalah akad kerjasama usaha antara dua pihak dimana pihak pertama (pemilik dana) menyediakan seluruh dana, sedangkan pihak kedua (pengelolah dana) bertindak selaku pengelolah, dan keuntungan dibagi antara mereka sesuai kesepakatan sedangkan kerugian finansial hanya ditanggung oleh pemilik dana. Para Ulama membagi Mudharabah menjadi dua jenis, yaitu: 1) Mudhalaqah, yaitu sistem Mudharabah dimana pemilik modal mejyerahkan modalnya kepada pengelolah tanpa pembatasan jenis usaha, tempat, waktu dan dengan siapa pengelola bertansaksi. Jenis ini memberikan kebebasan kepada mudharib (pengelolah modal) melakukan apa saja yang dipandang dapat mewujudkan kemaslahatan; 2) Muqayyadah (terbatas), yaitu pemilik modal menyerahkan modalnya kepada pengelola dan menentukan jenis usaha, tempat, waktu dan orang yang bertransaksi dengan mudharib (Muhammad, 2008).

Jenis kedua ini diperselisihkan para ulama keabsahan syaratnya, namun yang rajih dalam pembatasan tersebut berguna dan tidak sama sekali menyisihi dalil syar'i, itu hanya sekedar ijtihat dan dilakukan dengan kesepakatan dan kerhidaan antara kedua belah pihak sehingga wajib ditunaikan. Perbedaan antara keduanya terletak pada pemabtasan penggunaan modal sesuai permintaan investor (Sarwat, 2011). 


\section{PSAK 105 (Akuntansi Mudharabah)}

Pernyataan Standar Akuntansi Keuangan (PSAK) No.105 tentang akuntansi Mudharabah yang memuat pernyataan yang bertujuan untuk mengatur pengakuan, pengukuran, penyajian dan pengungkapan transaksi Mudharabah, baik untuk akuntansi untuk pemilik dana maupun akuntansi untuk pengelola dana.

Prinsip pembagian hasil usaha diatur dalam PSAK 105 pada paragraf 11 adalah Pembagian hasil usaha Mudharabah dapat dilakukan berdasarkan prinsip bagi hasil atau bagi laba. Jika berdasarkan prinsip bagi hasil, maka dasar pembagian hasil usaha adalah laba bruto (gross profit) bukan total pendapatan usaha (omset). Sedangkan jika berdasarkan prinsip bagi laba, dasar pembagian adalah laba neto (net profit) yaitu laba bruto dikurangi beban yang berkaitan dengan pengelolaan dana Mudharabah.

Tabel 1.

Contoh Net Profit dan Gross Profit

\begin{tabular}{ccc}
\hline Uraian & Jumlah & Metode Bagi Hasil \\
\hline Penjualan & 100 & \\
Harga Pokok Penjualan & 65 & Gross Profit Margin \\
Laba Kotor & 35 & \\
Beban & 25 & Profit Sharing \\
Laba Rugi Bersih & 10 &
\end{tabular}

(Sumber: Ikatan Akuntan Indonesia, 2007)

\section{Penelitian Terdahulu}

Terkait dengan bidang penelitian yang akan dilakukan, penulis mengambil beberapa referensi yang telah di teliti oleh penulis lain. Sari (2012) melakukan analisis pengakuan dan pengukuran terhadap pembiayaan Mudharabah berdasarkan PSAK 105 pada PT Bank Muamalat Indonesia TBK. Menurutnya penerapan akuntansi syariah pada pembiayaan bagi hasil Mudharabah PT. Bank Muamalat Indonesia, Tbk telah dilakukan dengan baik, karena pencatatan transaksi-transaksi sudah dilakukan sesuai Standar Akuntansi Keuangan. Penerapan akuntansi baik pengakuan, pengukuran, penyajian dan pengungkapan pembiayaan Mudharabah pada PT. Bank Muamalat Indonesia Tbk ini secara umum telah sesuai dengan PSAK No. 105.

Selanjutnya, Ginting (2017) melakukan analisis mengenai perlakuan PSAK 105 atas pembiayaan Mudharabah pada BMT Maslahah Sidogiri Cabang Wonorejo. Menurutnya terdapat beberapa perlakuan akuntansi Mudharabah yang belum sesuai dengan PSAK 105 yaitu pihak BMT Maslahah Sidogiri Cabang Wonorejo perlu memberikan aset non kas dan juga penerapan PSAK 105 paragraf 13 (b) yaitu 
pengukuran pembiayaan Mudharabah dalam bentuk aset non kas diukur sebesar nilai wajar asset non kas pada saat penyerahan, supaya lebih mempermudah nasabah dalam proses pengajuan pembiayaan yang berupa aset non kas.

\section{METODE PENELITIAN}

Penelitian ini menggunakan metode deskriptif kualitatif sehingga dalam langkah penelitiannya tidak perlu merumuskan hipotesis. Metode yang dilakukan dengan cara mengumpulkan, mempersiapkan, serta menganalisis data sehingga mendapat gambaran yang jelas mengenai masalah yang diteliti. Metode deskriptif Analisis merupakan metode penelitian dengan cara mengumpulkan data-data sesuai dengan yang sebenarnya kemudian data-data tersebut disusun, diolah dan dianalisis untuk dapat memberikan gambaran mengenai masalah yang ada.

Penelitian ini dilakukan di Bank Syariah Mandiri Cabang Jember yang beralamat di Jl. PB Sudirman No. 41-43, pagah, Jemberlor, Patrang, Kabupaten Jember, Jawa timur 68118. Waktu penelitian dilakukan selama 3 bulan. Data yang digunakan dalam penelitian in adalah data primer (responden) dan data sekunder (dokumentasi). Proses pengumpulan informasi maupun data dalam penelitian ini dilakukan dengan dua metode pengumpulan yaitu wawancara dan dokumentasi.

Dalam pengumpulan data yang diperoleh dari berbagai narasumber, sering dijumpai ketidaksamaan data. Trianggulasi adalah teknik keabsahan data yang memanfaatkan sesuatu yang lain. Dalam penelitian ini, penulis menggunkan triangulasi sumber yaitu dengan mewawancarai narasumber kemudian mambandingkan dengan hasil penelitian sebelumnya serta membandingkan hasil wawancara dengan dokumen atau arsip yang bersangkutan dengan transaksi Mudharabah. Adapun teknik yang digunakan dalam penelitian ini adalah analisis kualitatif dengan cara mendeskripsikan dan menggambarkan keadaan objek penelitian yang sesungguhnya untuk mengetahui dan menganalisis permasalahan yang dihadapi objek penelitian, kemudian dibandingkan dengan standar-standar yang menjadi acuan oleh peneliti selanjutnya mendeskripsikan apakah transaksi Mudharabah di Bank Syariah Mandiri Cabang Jember telah sesuai dengan PSAK 105. 


\section{HASIL PENELITIAN}

\section{Pengakuan dan Pengukuran}

\section{Akuntansi untuk Pemilik Dana}

Dana Mudharabah yang disalurkan oleh pemilik dana diakui sebagai investasi Mudharabah pada saat pembayaran kas atau penyerahan aset non kas kepada pengelola dana. Investasi Mudharabah dalam bentuk kas diukur sebesar jumlah yang dibayarkan. Investasi Mudharabah dalam bentuk aset non kas diukur sebesar nilai wajar aset nonkas pada saat penyerahan.

Bank Syariah Mandiri Cabang Jember mengakui dana Mudharabah yang diberikan sebagai investasi Mudharabah pada saat penyerahan modal kepada pengelola dana untuk modal berupa uang tunai (kas) dan tidak mengakui modal berupa non kas, dana Mudharabah tersebut akan diukur sebesar kas yang diberikan kepada pengelolah dana. Nasabah yang mengajukan pembiayaan Mudharabah harus memiliki rekening di Bank Mandiri Syariah, agar pembiayaan dapat dengan mudah direalisasikan dan akan langsung dilakukan melalui rekening nasabah yang bersangkutan. Sebagai contoh, Bank Mandiri Syariah menerima pengajuan pembiayaan dari Tuan X pada tanggal 16 november 2018 untuk periode satu tahun dengan jumlah nominal sebesar Rp.50.000.000,00.

Tabel 2.

Contoh Penjurnalan Pengajuan Pembiayaan oleh Bank Mandiri Syariah Cabang Jember

\begin{tabular}{llcl}
\hline \multicolumn{4}{c}{ Pengajuan Pembiayaan Mudharabah } \\
\hline 16 November 2018 & Debit & Pembiayaan Mudharabah & Rp50.000.000,00 \\
\hline & Kredit & Kas & Rp50.000.000,00 \\
\hline
\end{tabular}

Pengukuran pembiayaan Mudharabah atas kas yang sudah diterima oleh Bank Syariah Mandiri Cabang Jember di cacat di dalam laporan posisi keuangan pada akun dana syirkah temporer. Dana syirkah temporer adalah investasi dengan menggunakan akad Mudharabah mutlaqah dimana pemilik dana mempercayakan sepenuhnya atas dana investasi miliknya kepada mudharib atau pengelola dana, dalam hal ini adalah Bank Syariah Mandiri Cabang Jember.

Berdasarkan contoh jurnal di atas dan laporan posisi keuangan, maka dapat disimpulkan bahwa pengakuan dan pengukuran pembiayaan Mudharabah untuk penyataan di atas sudah sesuai dengan PSAK 105, yaitu : a) jika sebagian investasi Mudharabah hilang setelah dimulainya usaha tanapa adanya kelalaian atau kesalahan 
pengelola dana, maka kerugian tersebut akan diperhitungkan pada saat bagi hasil. Ketentuan tersebut sudah dijelaskan di catatan atas laporan keuangan dengan kalimat yang sama maka dengan demikian dapat disimpulkan ketentuan tersebut telah sesuai dengan PSAK 105; b) usaha Mudharabah dianggap mulai berjalan sejak dana atau modal usaha Mudharabah diterima oleh pengelola dana.

Berdasarkan wawancara dengan salah satu karyawan BSM Jember, beliau menyatakan bahwa: "perlakuan akuntansi yang dilakukan oleh pihak Bank Syariah Mandiri untuk akad pembiayaan Mudharabah mulai berjalan ketika pihak Bank Syariah Mandiri mulai mencairkan dana Mudharabah kepada nasabah sebagai pengelola dana." contoh pada transaksi diatas perlakuan akuntansi yang dilakukan oleh pihak Bank Syariah Mandiri mulai berjalan ketika pihak Bank Syariah Mandiri mulai mencairkan dana Mudharabah kepada firdaus, maka pernyataan di atas sudah sesuai dengan PSAK 105.

Berdasarakan kasus pembiayaan Mudharabah di atas Bank Syariah Mandiri Cabang Jember menerima laporan bahwa Tuan X melaporkan laba usaha sebesar Rp25.000.000,00 dengan nisbah bagi hasil yang telah disepakati sebesar Rp10.000.000,00 (40\% x Rp25.000.000,00). Dalam pembiayaan Mudharabah pendapatan bagi hasil nasabah kepada Bank Syariah Mandiri, pembayaran pendapatan bagi hasil dilakukan setiap bulan. Bank Syariah Mandiri Cabang Jember mencatat jurnal:

Tabel 3.

Penjurnalan Pembiayaan Mudharabah Pendapatan Bagi Hasil Nasabah Kepada Bank Mandiri Syariah Cabang Jember

\begin{tabular}{ccc}
\hline \multicolumn{3}{c}{ Pembiayaan Mudharabah Pendapatan Bagi Hasil Nasabah } \\
\hline Debit & Kas & Rp10.000.000,00 \\
\hline Kredit & Pendapatan Bagi Hasil & Rp10.000.000,00 \\
\hline
\end{tabular}

Jika akad Mudharabah berakhir sebelum atau saat akad jatuh tempo dan belum dibayar oleh pengelola dana, maka investasi Mudharabah diakui sebagai piutang. Dengan demikian, bagi hasil yang belum dibayarkan oleh mudharib pada saat jatuh tempo kepada Bank Syariah Mandiri Cabang Jember akan diakui sebagai piutang jatuh tempo sebesar bagi hasil yang menjadi porsi pemilik dana pada periode yang bersangkutan. Sedangkan, rugi yang terjadi akan diakui pada periode tersebut dan mengurangi saldo pembiayaan. (PSAK 105). 
Sebagai contoh, Bank Syariah Mandiri Cabang Jember menerima laporan dari Tuan X bahwa masih ada bagi hasil yang menjadi porsi bank pada akhir periode pembiayaan sebesar Rp3.500.000,00, maka Bank Syariah Mandiri Cabang Jember mencatat/menjurnalnya sebagai berikut:

Tabel 4.

Penjurnalan Bagi Hasil yang Menjadi Porsi Bank Mandiri Syariah Cabang Jember

\begin{tabular}{ccc}
\hline \multicolumn{3}{c}{ Sistem Bagi Hasil yang Menjadi Porsi Bank } \\
\hline Debit & Piutang jatuh tempo & Rp3.500.000,00 \\
\hline Kredit & Pendapatan Bagi Hasil & Rp3.500.000,00 \\
\hline
\end{tabular}

Kerugian yang terjadi dalam suatu periode sebelum akad Mudharabah berakhir diakui sebagai kerugian dan dibentuk penyisihan kerugian investasi. Kerugian yang terjadi akan ditanggung oleh pengelolah modal apabila kerugian tersebut disebabkan kesalahan yang disengaja, lalai atau menyalahi perjanjian oleh pengelola modal dan Bank Syariah Mandiri Cabang jember didalam laporan posisi keuangan telah melakukan pencatatan penyisihan kerugian investasi di setiap investasi yang dilakukan, sehingga apabila terjadi kerugian dalam investasi Mudharabah tidak akan mengurangi nilai invetasi melainkan akan diambilkan dari penyisihan kerugian yang telah ditetapkan oleh bank. jadi syarat tersebut telah terpenuhi.

Selanjutnya, kerugian yang terjadi dalam suatu periode sebelum akad Mudharabah berakhir diakui sebagai selisih antara: investasi Mudharabah setelah dikurangi penyisihan kerugian investasi, dan pengembalian investasi Mudharabah diakui sebagai keuntungan atau kerugian. Kreteria tersebut sudah sesuai dengan yang diterapkan oleh Bank Syariah Mandiri Cabang Jember. kerugian diakui berdasarkan selisih antara investasi Mudharabah dengan cadangan kerugian investasi. setiap investasi sesuai dengan laporan posisi keuangan telah disertakan akun penyisihan kerugian, sehingga nilai investasi tidak akan berkurang apabila benar-benar terjadi kerugian. jadi syarat pengembalian investasi Mudharabah diakui sebagai keuntungan atau kerugian telah terpenuhi.

Penentuan kerugian pada Bank Syariah Mandiri telah sesuai dengan PSAK 105 terkait kerugian akibat pengelola dana akan ditanggung oleh pengelola dana tanpa mengurangi pembiayaan Mudharabah. Hal ini telah dijelaskan di dalam catatan atas laporan keuangan Bank Syariah Mandiri. Jadi syarat diatas sudah terpenuhi. Adapun 
bagian hasil usaha yang belum dibayar oleh pengelola, diakui sebagai piutang. Proses bagi hasil yang belum dibayarkan oleh mudharib pada saat jatuh tempo kepada Bank Syariah Mandiri Cabang Jember akan diakui sebagai piutang jatuh tempo sebesar bagi hasil yang menjadi porsi pemilik dana pada periode yang bersangkutan. Sedangkan, rugi yang terjadi akan diakui pada periode tersebut dan mengurangi saldo pembiayaan.

\section{Akuntansi untuk Pengelolah Dana}

Dana yang diterima dari pemilik dana dalam akad Mudharabah diakui sebagai dana syirkah temporer sebesar jumlah kas atau nilai wajar aset yang diterima. Pada akhir periode akuntansi, dana syirkah temporer diukur sebesar nilai tercatatnya. Jika pengelola dana menyalurkan dana syirkah temporer yang diterima, maka pengelola dana mengakuinya sebagai aset. Ketentuan tersebut telah diterapkan oleh Bank Syariah Mandiri Cabang Jember untuk pendanaan Mudharabah masuk neraca dan sistem bagi hasil diakui di laporan rugi laba.

Berdasarkan neraca Bank Syariah Mandiri Cabang Jember, pendanaan berasal dari kas, penempatan pada BI, penempatan pada bank lain, surat berharga, piutang murabahah, piutang Ijarah, piutang Istishna, dan piutang Qardh. Sementara pendanaan Mudharabah Bank Syariah Mandiri Cabang Jember juga diakui dalam neraca sebagai dana Syirkah temporer dan keuntungan bagi hasil Bank Syariah Mandiri Cabang Jember dicatat pada laporan laba rugi sebagai pendapatan dari bagi hasil. Pendanaan Mudharabah ini tidak ada dana dalam bentuk non kas sehingga pendanaan Mudharabah ini diukur dari dana dalam bentuk kas dinilai sebesar jumlah yang diterima.

Selanjutnya pengelola dana harus mengakui pendapatan atas pengaluran dana syirkah temporer secara bruto sebelum dikurangi dengan bagian hak pemilik dana. Penyaluran dana syirkah temporer di Bank Syariah Mandiri Cabang Jember telah sesuai dengan kreteria tersebut, penjelasan tersebut tertera di laporan laba rugi bahwa pendapatan pengelolahan dana oleh bank sebagai pengelola dana diakui sebelum dikurangi hak pihak ketiga atas dana syirkah temporer.

Bagi hasil Mudharabah dapat dilakukan dengan menggunakan dua prinsip, yaitu bagi laba atau bagi hasil. Bank Syariah Mandiri Cabang Jember dalam menentukan bagi hasil menggunakan laba bruto untuk penghimpunan dana sesuai dengan ilustrasi berikut: 


\section{Perhitungan Bagi Hasil}

Pak Sarman mempunyai saldo rata-rata tabungan bulan Agustus 2018 Rp1.000.000,00 dan perbandingan bagi hasil (nisbah) antara Bank dan nasabah 85\% : 15\% untuk rata-rata tabungan seluruh nasabah BSM Cab.Jember pada bulan Agustus Rp2.000.000.000,00 dan pendapatan bank yang dibagi hasilkan untuk nasabah tabungan adalah Rp200.000.000,00, maka bagi hasil yang diterima Pak Sarman adalah:

Perhitungan: $\frac{\mathrm{Rp} 1.000 .000,00}{\mathrm{R} 2.000 .000 .000,00} \times \mathrm{Rp} 200.000 .000,00 \times 15 \%=\mathrm{Rp} .15 .000$

(Sebelum dipotong pajak/laba Bruto)

Dengan demikian, bagi hasil yang diterima oleh Pak Sarman adalah Rp15.000.

Kerugian yang diakibatkan oleh kesalahan atau kelalaian pengelola dana diakui sebagai beban pengelola dana. Pernyataan di tersebut sudah jelas diterangkan di dalam catatan atas laporan keuangan Bank Syariah Mandiri Cabang Jember yaitu berada di ikhtisar kebijakan akuntansi yang menyatakan bahwa kerugian yang diakibatkan oleh kesalahan atau kelalaian pengelola dana diakui sebagai beban pengelola dana.

\section{Penyajian}

Pemilik dana menyajikan investasi Mudharabah dalam laporan keuangan sebesar nilai tercatat. Pengelola dana menyajikan transaksi Mudharabah dalam laporan keuangan: 1) dana syirkah temporer dari pemilik dana disajikan sebesar nilai tercatatnya untuk setiap jenis Mudharabah; 2) bagi hasil dana syirkah temporer yang sudah diperhitungkan tetapi belum diserahkan kepada pemilik dana disajikan sebagai pos bagi hasil yang belum dibagikan di kewajiban.

Penyajikan pembiayaan Mudharabah pada Bank Syariah Mandiri Cabang Jember disajikan di neraca sebesar tagihan bank kepada nasabah. Penyajian pendanaan Mudharabah pada Bank Syariah Cabang Jember disajikan sama di dalam neraca, pendanaan terdiri dari tabungan Mudharabah dan deposito Mudharabah baik dengan rupiah atau valas. Pendapatan bagi hasil disajikan di laporan laba rugi. 


\section{Pengungkapan}

Pemilik dana mengungkapkan hal-hal terkait transaksi Mudharabah, tetapi tidak terbatas pada: 1) isi kesepakatan utama usaha Mudharabah, seperti porsi dana, pembagian hasil usaha, aktivitas usaha Mudharabah dan lain-lain; 2) rincian jumlah investasi Mudharabah berdasarkan jenisnya; 3) penyisihan kerugian investasi Mudharabah selama periode berjalan; 4) pengungkapan yang diperlukan sesuai PSAK 101: Penyajian Laporan Keuangan Syariah.

Pengungkapan yang berkaitan bank sebagai pemilik dana di Bank Syariah Mandiri disajikan di dalam Catatan Atas Laporan Keuangan yang berisi pembiayaan yang diberikan seperti jumlah aktiva produktif yang diberikan kepada nasabah, ikhtisar perubahan penyisihan kerugian dan penghapusan aktiva produktif tahun bersangkutan. Bank Mandiri Syariah Cabang Jember juga harus mengungkapkan seperti jenis aset produktif dan sektor ekonomi. Hal ini telah sesuai dengan PSAK No. 105 yang menyatakan tentang jenis aset produktif, sektor ekonomi dan jumlah aset produktif masing-masing. Ikhtisar perubahan penyisihan kerugian dan penghapusan aset produktif yang diberikan dalam tahun yang bersangkutan menunjukkan saldo awal, penyisihan selama tahun berjalan, penghapusan selama tahun berjalan, pembayaran aset produktif yang telah dihapusbukukan dan saldo penyisihan pada akhir tahun.

Pengelola dana mengungkapkan hal-hal terkait transaksi Mudharabah, tetapi tidak terbatas, pada: 1) isi kesepakatan utama usaha Mudharabah, seperti porsi dana, pembagian hasil usaha, aktivitas usaha Mudharabah dan lain-lain; 2) rincian dana syirkah temporer yang diterima berdasarkan jenisnya; 3) penyaluran dana yang berasal dari Mudharabah muqayadah; 4) pengungkapan yang diperlukan sesuai PSAK 101: Penyajian Laporan Keuangan Syariah.

Berdasarkan penelitian di Bank Syariah Mandiri Cabang Jember, pendanaan dilakukan dalam neraca, laporan laba rugi dan laporan bagi hasil diungkapkan sesuai dengan periode pendanaan. Selain itu di neraca dan laporan laba rugi serta laporan bagi hasil di PT. Bank Syariah Mandiri Cabang Jember mengungkapkan jumlah dana dan jumlah bagi hasil diterima selama periode laporan beserta jenisnya. Hal ini telah sesuai dengan PSAK 105. 


\section{PEMBAHASAN}

Berdasarkan hasil penelitian, sistem pengakuan, pengukuran, penyajian dan pengungkapan transaksi Mudharabah di Bank Syariah Mandiri Cabang Jember sudah hampir sesuai dengan PSAK 105, namun ada beberapa pernyataan yang belum sesuai dengan PSAK 105 yaitu: Bank Syariah Mandiri Cabang Jember dalam transaksi Mudharabah hanya menggunakan aset dalam bentuk kas untuk pendanaan dan tidak melakukan pendanaan Mudharabah dalam bentuk asset non kas. Sedikit berbeda dengan Bank Syariah Mandiri KCP Lawang, menurut Iltiham (2019) bahwa penerapan akad Mudharabah di Bank Syariah Mandiri ini telah sesuai dengan standar akuntansi akad Mudharabah yang tertuang pada PSAK 105 tentang Akuntansi Mudharabah dan juga telah sesuai dengan ketentuan Fatwa DSN MUI tentang Pembiayaan Mudharabah.

Selain Bank Syariah Mandiri, Bank Mega Syariah KC Semarang juga telah menggunakan akad Mudharabah mutlaqah dalam melaksanakan operasionalnya. Ditinjau dari perspektif Islam, penggunaan akad ini juga tidak bertentangan dengan syariat Islam karena prinsip yang diterapkan di dalam produk ini sesuai dengan prinsip syariah Islam yang 10 penerapannya menggunakan prinsip bagi hasil yang dihasilkan dari produk yang halal. Bank bertindak sebagai pelaksana usaha (Mudharib) dan nasabah bank bertindak sebagai pemilik dana (Shahibul Maal). Dana tersebut digunakan bank untuk melakukan Murabahah atau Ijarah. Melalui hasil pengelolaan dana mudharabah, Bank Mega Syariah akan membagikan hasil keuntungan kepada pemilik dana sesuai dengan nisbah yang telah disepakati diawal akad pembukaan rekening (Mustofa, 2016).

Sebagai bentuk kerja sama antara dua pihak untuk menjalankan suatu usaha atau bisnis tertentu, pelaksana Mudharabah harus memperhatikan bahwa apabila terjadi kerugian maka yang menanggung seluruh kerugian adalah pihak pemilik modal, kecuali kerugian terjadi karena kelalaian pihak yang menjalankan usaha, sementara apabila usaha tersebut mendapatkan keuntungan, maka dibagi sesuai dengan kesepakatan diantara mereka (Mustofa, 2016). Dengan kata lain, keuntungan tidak boleh dihitung berdasarkan persentase dari jumlah modal yang diberikan Sahibul Maal. Perhitungan bagi hasil harus berdasarkan keuntungan yang didapat (Ulfah, 2017). 


\section{SIMPULAN}

Transaksi Mudharabah menurut Bank Syariah Mandiri Cabang Jember, Bank bertindak sebagai pengelolah dana dan pemilik dana. Bank Syariah Mandiri Cabang Jember bertindak sebagai pemilik dana pada produk pembiayaan, sedangkan Bank bertindak sebagai pengelola dana pada produk tabungan dan deposito.

Kerugian finansial akan ditanggung oleh pemilik dana. Selama kerugian tersebut bukan merupakan kesalahan atau kelalaian pengelola dana. Hal tersebut karena pemilik dana mempunyai porsi modal $100 \%$, sedangkan pengelolah dana tidak berkontribusi dalam modal. Namun, apabila kerugian terjadi karena pelanggaran akad oleh pengelola dana, maka akan mengurangi investasi Mudharabah.

Pengakuan, pengukuran, penyajian dan pengungkapan transaksi Mudharabah di Bank Syariah Mandiri Cabang Jember sudah hampir sesuai dengan PSAK 105, namun ada beberapa pernyataan yang belum sesuai dengan PSAK 105 yaitu: Bank Syariah Mandiri Cabang Jember dalam transaksi Mudharabah hanya menggunakan aset dalam bentuk kas untuk pendanaan, tidak melakukan pendanaan Mudharabah dalam bentuk asset non kas.

\section{DAFTAR PUSTAKA}

Ginting, K. P. (2017). Perlakuan PSAK 105 Atas Pembiayaan Mudharabah pada BMT Maslahah Sidogiri Cabang Wonerejo. Undergraduate Thesis. Universitas Islam Negeri Maulana Malik Ibrahim

Harahap, S. S. (1997). Akuntansi Islam. Jakarta: Bumi Aksara

Hidayat, Y. R., \& Surahman, M. (2017). Analisis Pencapaian Tujuan Bank Syariah Sesuai UU No 21 Tahun 2008. Amwaluna: Jurnal Ekonomi dan Keuangan Syariah, 1(1), 34-50

Ikatan Akuntan Indonesia. (2007). Pedoman Syariah Akuntansi Keuangan (PSAK 105 Akuntansi Mudharabah). Jakarta: Dewan Standar Akuntansi Keuangan

Iltiham, M. F. (2019). Implementasi Akad Mudharabah Berdasarkan PSAK 105 tentang Akuntansi Mudhrabah dan Fatwa DSN MUI pada Produk Pembiayaan. Malia: Jurnal Ekonomi Islam, 11(1), 21-38

Muhammad, M. (2008). Manajemen Pembiayaan Mudharabah di Bank Syariah. Jakarta: Rajagrafindo Persada

Mustofa, I. (2016). Fiqh Muamalah Kontemporer. Jakarta: Raja Grafindo Persada

Mustofa, J. (2016). Penerapan Akad Mudharabah pada Produk Tabungan Haji IB Mega Syari'ah di Bank Mega Syari'ah KC Semarang. Skripsi. UIN Walisongo Semarang 
Sari, S. N. (2012). Analisis Pengakuan dan Pengukuran pada Pembiayaan Mudharabah berdasarkan PSAK No. 105 (Studi Kasus pada PT BankMuamalat Indonesia Tbk). Skripsi. Universitas Gunadarma

Sarwat, A. (2011). Seri Fiqih Kehidupan (7) Muamalah. Jakarta: Du Publishing

Ulfah, M. (2017). Tinjauan Hukum Islam terhadap Pelaksanaan Akad Mudharabah pada Simpanan Berkah Discounted (Studi Kasus di BMT Taruna Sejahtera Jatisari Mijen Semarang). Skripsi. Universitas Islam Negeri Walisongo

Undang-Undang RI No. 21. (2008). Perbankan Syariah. https://www.ojk.go.id/waspadainvestasi/id/regulasi/Documents/UU_No_21_Tahun_2008_Perbankan_Syariah.p df 